\title{
ANALISIS DINAMIK PERILAKU GEDUNG DENGAN KETIDAKBERATURAN MASSA PADA MASING-MASING TINGKAT TERHADAP BEBAN GEMPA
}

\author{
Leonardus Ivan ${ }^{1}$ dan Edison Leo ${ }^{2}$ \\ ${ }^{1}$ Program Studi Sarjana Teknik Sipil, Universitas Tarumanagara, Jl. Letjen S. Parman No.1 Jakarta \\ Email: ivan.leonardus@gmail.com \\ ${ }^{2}$ Program Studi Sarjana Teknik Sipil, Universitas Tarumanagara, Jl. Letjen S. Parman No.1 Jakarta \\ Email: edisonl@ft.untar.ac.id
}

\begin{abstract}
ABSTRAK
Di Indonesia, gempa bumi merupakan bencana alam yang sangat sering terjadi. Intensitas terjadinya gempa yang tinggi di Indonesia akibat posisinya yang berada di pertemuan tiga lempeng tektonik dan posisinya yang berada di daerah Cincin Api Pasifik yang merupakan sabuk gempa bumi terbesar di dunia. Namun, sebenarnya bukan gempa bumi yang menyebabkan korban, melainkan disebabkan oleh bangunan yang rubuh karena tidak mampu merespons dengan baik getaran gempa. Ketidakmampuan struktur merespons getaran gempa, salah satunya adalah akibat terdapatnya ketidakberaturan struktur. Ketidakberaturan struktur yang akan dibahas pada Skripsi ini adalah ketidakberaturan massa. Struktur yang dimodelkan adalah gedung bertingkat yang memiliki ketidakberaturan massa sebesar 300\% pada setiap tingkat secara terpisah. Gedung yang dimodelkan memiliki 10 tingkat dan terletak pada Kota Lombok. Gedung dianalisis secara dinamik menurut SNI 1726:2012 dengan bantuan program ETABS, terhadap beban gempa. Analisis dinamik yang digunakan adalah analisis ragam respons spektrum dan analisis ragam riwayat waktu. Respons gedung yang ditinjau adalah gaya geser tingkat, simpangan lateral tingkat, dan simpangan antar lantai tingkat pada masing-masing pemodelan gedung. Hasil perbandingan menunjukkan bahwa beban gempa hasil kedua analisis dinamik memiliki deviasi yang kecil. Dengan demikian, kedua analisis dinamik relatif dapat menggambarkan beban gempa yang akan terjadi sebenarnya. Hasil analisis yang didapat menggunakan kedua metode analisis dinamik tersebut, menunjukkan bahwa ketidakberaturan massa dinyatakan relatif aman jika berada pada 10$20 \%$ ketinggian gedung and dinyatakan berbahaya jika diletakkan pada ketinggian paling atas dan 90\%, 70\%, 40\%, dan 30\% dari ketinggian gedung.
\end{abstract}

Kata kunci: analisis dinamik, ketidakberaturan massa, perencanaan gempa, SNI 1726:2012, ETABS

\section{PENDAHULUAN}

\section{Latar Belakang}

Gempa bumi merupakan peristiwa yang sangat umum dan sering terjadi di negara-negara di seluruh bumi, termasuk juga di Indonesia. Intensitas yang tinggi dari terjadinya gempa bumi di Indonesia adalah karena posisinya di antara pertemuan 3 lempeng utama dunia, serta berada di dalam Cincin Api pasifik yang merupakan sabuk gempa bumi terbesar di bumi. Namun sebenarnya bukan gempa bumi yang menyebabkan korban jiwa, melainkan struktur bangunan yang rubuh akibat tidak dapat merespon gempa dengan baik. Penyebab dari ketidakmampuan ini adalah akibat adanya ketidakberaturan struktur dalam suatu bangunan. Salah satu jenis ketidakberaturan struktur yang sering terjadi adalah ketidakberaturan massa. Ketidakberaturan massa dapat terjadi pada suatu struktur jika massa dalam suatu tingkat lebih besar dari 150\% massa tingkat dibawahnya. Salah satu penyebabnya adalah karena kebutuhan arsitektur (Sadashiva dkk, 2009:288), misalnya keberadaan ruang mesin atau gudang dalam suatu tingkat pada suatu gedung. Kasus lainnya adalah suatu tingkat dalam gedung yang direncanakan akan berfungsi sebagai area kolam renang. Selain karena kebutuhan arsitektur, dapat juga terjadi karena pengalihan fungsi bangunan. Misalnya seperti studi kasus dalam penelitian yang dilakukan oleh Christiawan dkk (2008) yaitu alih fungsi ruang kuliah pada lantai II Gedung G Universitas Semarang menjadi ruang perpustakaan. Perubahaan fungsi ruang tersebut biasanya dilakukan berdasarkan pertimbangan efesiensi pemanfaatan ruang dari segi pembiayaan dan ketersediaan lahan.

\section{Tujuan}

Tujuan dari penelitian ini adalah untuk membandingkan beberapa parameter respons dari gedung yang memiliki ketidakberaturan massa terhadap gedung beraturan, menggunakan analisis dinamik dengan bantuan program 
ETABS pada masing-masing tingkat, sehingga dapat diketahui tingkat mana yang paling aman hingga paling berbahaya untuk diberikan ketidakberaturan massa.

\section{Batasan Masalah}

Bangunan yang dimodelkan dalam penelitian ini adalah gedung 10 tingkat yang berada di kota Lombok dengan kelas situs tanah lunak yang memiliki ketidakberaturan massa sebesar 300\% pada tingkat yang berbeda-beda secara terpisah pada masing-masing pemodelan gedung. Gedung yang direncanakan mengikuti ketentuan-ketentuan perencanaan hanya gedung beraturan. Gedung yang memiliki ketidakberaturan massa dibiarkan melewati ketentuan tersebut untuk mengetahui seberapa besar penyimpangan yang terjadi.

\section{DASAR TEORI}

\section{Ketidakberaturan Massa}

Menurut Tabel 11 SNI 1726:2012, Ketidakberaturan berat (massa) didefinisikan ada jika massa efektif semua tingkat lebih dari 150\% massa efektif didekatnya. Atap yang lebih ringan dari lantai bawahnya tidak perlu ditinjau.

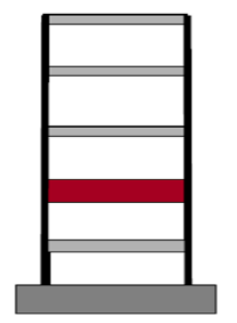

Gambar 1. Illustrasi Ketidakberaturan Massa

(Sumber: Instructional Material Complementing FEMA 451, Design Examples)

\section{Metode Analisis Dinamik}

Analisis dinamik untuk perancangan struktur tahan gempa dilakukan jika diperlukan evaluasi yang lebih akurat dari gaya-gaya gempa yang bekerja pada struktur, serta untuk mengetahui perilaku dari struktur akibat pengaruh gempa. Pada struktur bangunan tingkat tinggi atau struktur dengan bentuk atau konfigurasi yang tidak teratur. Analisis dinamik dapat dilakukan dengan cara elastis maupun inelastis. Pada cara elastis, analisis dibedakan menjadi 2 metode analisis, yaitu analisis ragam spektrum respons (response spectrum modal analysis) dan ragam riwayat waktu (time history modal analysis). Pada analisis ragam spektrum respons, struktur diberikan suatu spektrum respons dari gempa rencana yang kemudian ditentukan respons struktur terhadap pengaruh suatu gempa melalui superposisi dari respons tiap getarnya. Pada analisis ragam riwayat waktu, memerlukan masukan data rekaman percepatan gempa untuk menganalisa respon dinamik struktur yang menerima beban yang berubah-ubah terhadap waktu.

\section{Gaya Geser Dasar (Base Shear) dan Gaya Geser Tingkat (Story Shear)}

Gaya geser dasar merupakan pengganti atau penyederhanaan dari getaran gempa bumi yang bekerja pada dasar bangunan dan selanjutnya digunakan sebagai gaya gempa rencana yang harus ditinjau dalam perencanaan dan evaluasi struktur bangunan gedung. Gaya geser dasar pada struktur gedung beraturan dapat ditentukan dengan metode statik ekivalen, sedangkan untuk struktur gedung tidak beraturan ditinjau dengan metode dinamik.

Gaya geser dasar akan didistribusikan secara vertikal sepanjang tinggi struktur sebagai gaya horizontal tingkat yang bekerja pada masing-masing tingkat bangunan. Penjumlahan gaya horizontal pada tingkat yang ditinjau dapat disebut dengan gaya geser tingkat. Akibat dari gaya geser pada suatu tingkat, maka akan mengakibatkan terjadinya perpindahan dan simpangan pada tingkat-tingkat tersebut.

\section{Simpangan Lateral Tingkat dan Simpangan Antar Lantai Tingkat}

Simpangan lateral tingkat (story displacement) adalah perpindahan lateral suatu tingkat yang diukur dari dasar bangunan, sedangkan simpangan antar lantai tingkat (story drift) adalah perpindahan lateral relatif antara dua tingkat bangunan yang berdekatan atau simpangan mendatar tiap tingkat bangunan yang diukur dari lantai di bawahnya.

Simpangan antar lantai tingkat desain $(\Delta)$ dihitung sebagai selisih terbesar dari defleksi titik-titik di atas dan di bawah tingkat yang ditinjau dan letaknya segaris secara vertikal, disepanjang salah satu bagian tepi struktur. Defleksi pusat massa pada tingkat $\mathrm{x}\left(\delta_{\mathrm{x}}\right)(\mathrm{mm})$ harus ditentukan berdasarkan persamaan sebagai berikut: 
Keterangan:

$$
\delta_{x}=\frac{c_{d} \delta_{e x}}{I_{e}}
$$

$C_{d}=$ faktor amplifikasi defleksi

$\delta_{e x}=$ simpangan lateral elastis akibat gaya gempa desain pada tingkat $x$

$I_{e} \quad=$ faktor keutamaan gempa yang

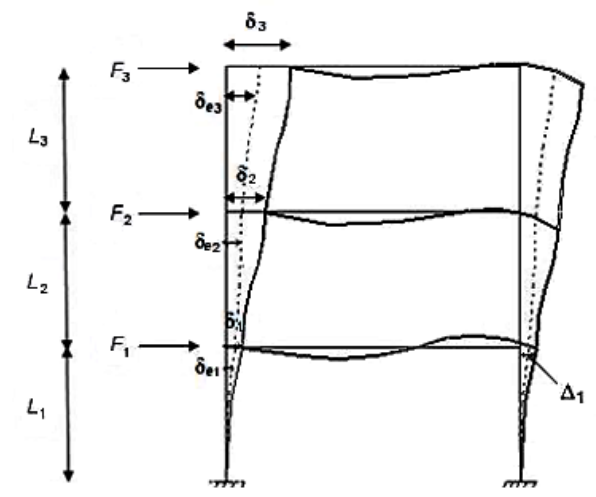

Gambar 2. Penentuan Simpangan Antar Lantai

(Sumber: SNI 1726:2012)

Keterangan:

$F_{i} \quad$ = gaya geser dasar seismik pada tingkat $\mathrm{i}$

$\delta_{e i}=$ simpangan lateral elastis akibat gaya gempa desain pada tingkat $\mathrm{i}$

$\delta_{i}=C_{d} \delta_{e i} / I_{e}=$ simpangan lateral yang diperbesar pada tingkat i

$\Delta_{i}=\left(\delta_{e i}-\delta_{e(i-1)}\right) C_{d} / I_{e}=$ simpangan antar lantai pada tingkat i yang diperbesar

Simpangan antar lantai tingkat yang diperbesar, $\Delta_{\mathrm{x}}$ tidak boleh melebihi simpangan antar lantai tingkat yang diiizinkan, $\Delta_{\mathrm{a}}$ seperti yang dirujuk dalam Tabel 1 di semua tingkat.

Tabel 1. Simpangan Antar Lantai Izin $\left(\Delta_{a}\right)$ Berdasarkan SNI 1726:2012

\begin{tabular}{lccc}
\hline \multicolumn{1}{c}{ Struktur } & \multicolumn{1}{c}{ Kategori Resiko } \\
\cline { 2 - 4 } & I atau II & III & IV \\
\hline $\begin{array}{l}\text { Struktur selain dari struktur dinding geser batu bata, } 4 \text { tingkat atau } \\
\text { kurang dengan dinding interior, partisi, langit-langit dan sistem } \\
\text { dinding eksterior yang telah didesain } \\
\text { simpangan antar lantai tingkat }\end{array}$ & $0.025 h_{s x}$ & $0.020 h_{s x}$ & $0.015 h_{s x}$ \\
\hline Struktur dinding geser kantilever atau bata & & & \\
\hline Struktur dinding geser batu bata lainnya & $0.010 h_{s x}$ & $0.010 h_{s x}$ & $0.010 h_{s x}$ \\
\hline Semua struktur lainnya & $0.007 h_{s x}$ & $0.007 h_{s x}$ & $0.007 h_{s x}$ \\
\hline
\end{tabular}

Keterangan:

$h_{s x}=$ tinggi tingkat di bawah tingkat $x$

\section{METODE PENELITIAN}

Langkah pertama yang dilakukan dalam penelitian ini adalah dengan melakukan berbagai studi literatur mengenai hal-hal yang diperlukan. Setelah itu dilakukan pemodelan struktur pada program ETABS, baik beraturan dan struktur yang memiliki ketidakberaturan massa pada masing-masing tingkat sesuai dengan ketentuan dan asumsi yang telah ditentukan. Kemudian dilanjutkan dengan pembebanan gedung dengan beban mati, beban hidup, dan beban gempa. Beban gempa yang digunakan adalah hasil analisis dinamik spektrum respons dan riwayat waktu. Setelah semua selesai, pada masing-masing model akan dilakukan pengecekan terhadap syarat partisipasi massa ragam, pengecekan terhadap kemungkinan terjadinya ketidakberaturan selain ketidaberaturan massa, dan pengecekan terhadap kapasitas momen dan lendutan pelat (terutama pada gedung yang memiliki ketidakberaturan massa). Jika semua pemodelan sudah sesuai dengan syarat-syarat pengecekan, maka dilakukan analisis struktur menggunakan program ETABS untuk mendapatkan parameter-parameter respons gedung berupa gaya geser tingkat (story shear), dan simpangan antar lantai tingkat (story drift). Parameter-parameter tersebut kemudian dibandingkan antara model gedung beraturan dengan model-model gedung yang memiliki ketidakberaturan massa pada masingmasing tingkat. 


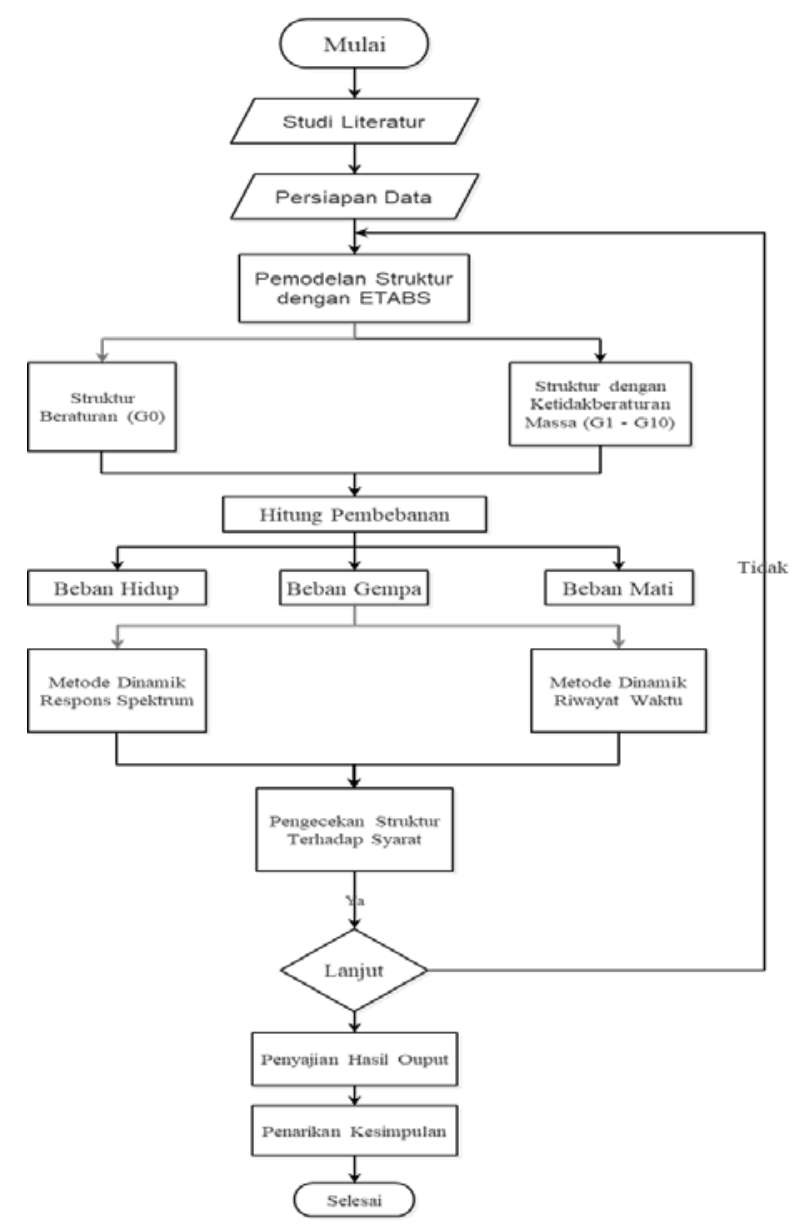

Gambar 3. Diagram Alir Penelitian

\section{Data Struktur}

Pada penelitian ini terdapat total 11 model gedung 10 tingkat. Model pertama adalah gedung yang beraturan (G0) dan sisanya model gedung yang memiliki ketidakberaturan massa sebesar 300\% pada masing-masing tingkat. Datadata teknis yang digunakan dalam pemodelan gedung pada penelitian ini adalah sebagai berikut:
a. Lokasi Bangunan
: Lombok
b. Fungsi Bangunan
: Gedung Perkantoran
c. Jarak Antar Tingkat
: 5 m (lantai 1) ; 4 m (lantai 2 - lantai 10)
d. Jenis Konstruksi
: Struktur Beton Bertulang
e. Jenis Tanah
: Tanah Lunak (Kelas Situs E)

f. Dimensi Elemen Struktur

- Balok

$$
\begin{array}{ll}
\text { GF }- \text { St. } 6 & =300 \times 600 \mathrm{~mm}^{2} \text { [1] } \\
\text { St. } 7-\text { ROOf } & =250 \times 500 \mathrm{~mm}^{2}[2] \\
& =250 \times 500 \mathrm{~mm}^{2}[1] \\
&
\end{array}
$$

- Pelat Lantai GF - ROOF

g. Mutu Material

$$
=150 \mathrm{~mm} \text { (untuk gedung beraturan) }
$$

= $275 \mathrm{~mm}$ (untuk gedung tidakberaturan pada tingkat 1 dan 3-10)

= $285 \mathrm{~mm}$ (untuk gedung tidakberaturan pada tingkat 2)
- Kolom

$$
\text { GF - ST. } 2=600 \times 600 \mathrm{~mm}^{2}
$$

St. 3 - St. $6=500 \times 500 \mathrm{~mm}^{2}$

St. 7 - ROOF $=450 \times 450 \mathrm{~mm}^{2}$
- Mutu Beton (f'c)
Kolom GF - St. 2
$=37 \mathrm{MPa}$
$\begin{array}{ll}\text { Kolom St } 3-\text { ROOF } & =35 \mathrm{MPa} \\ \text { Balok \& Pelat } & =30 \mathrm{MPa}\end{array}$
- Mutu Tulangan Baja Tulangan Pokok $\quad=400 \mathrm{MPa}$ Tulangan Geser $\quad=400 \mathrm{MPa}$

Keterangan $\quad:[1] \rightarrow$ Untuk Bentang $6 \mathrm{~m}$; [2] $\rightarrow$ Untuk Bentang $4 \mathrm{~m}$ dan $3 \mathrm{~m}$ 


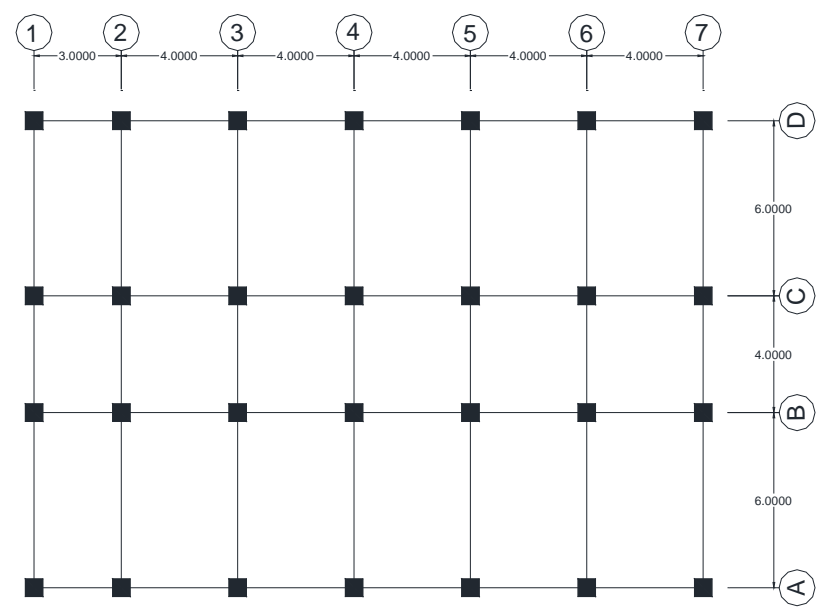

Gambar 4. Denah Struktur yang Direncanakan

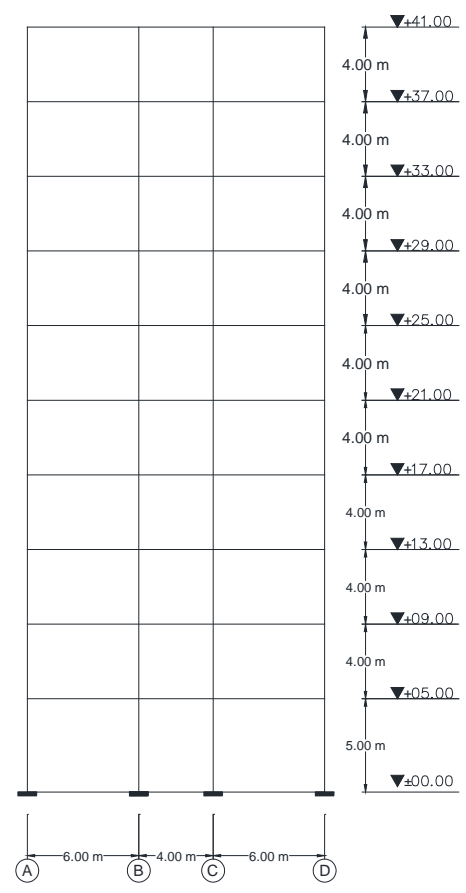

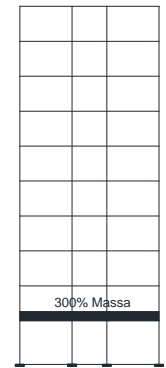

G1

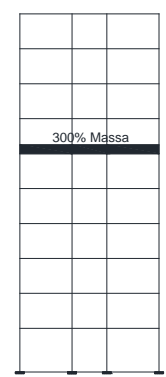

G6

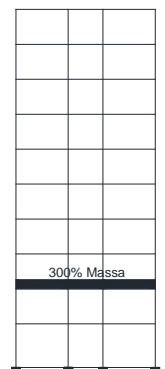

G2

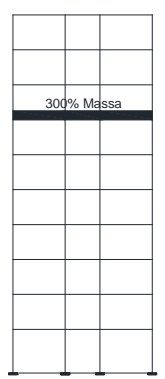

G7

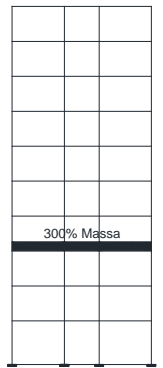

G3

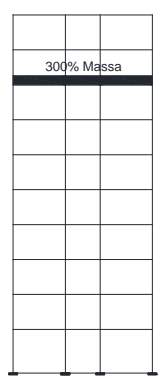

G8

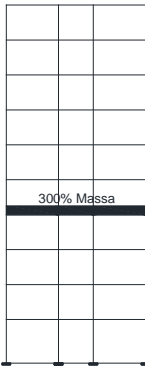

G4

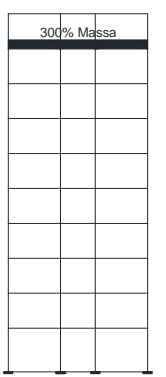

G9

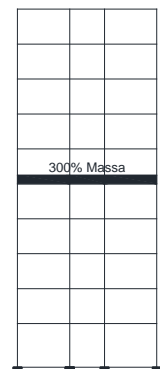

G5

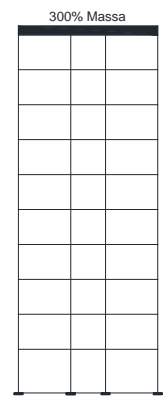

G10

G0

Gambar 5. Tampak Elevasi Model Gedung G0 - G10

\section{HASIL DAN PEMBAHASAN}

Berikut ini merupakan hasil-hasil (output) yang didapatkan dari hasil analisis menggunakan program ETABS serta pembahasannya. Semua hasil didapatkan berdasarkan analisis dinamik ragam spektrum respons (RS), ragam riwayat waktu menggunakan data riwayat gempa hasil simulasi program SIMQKE (TH - SMQ), Chuetsu-Oki (TH - CHT), dan Niigata (TH - NGT).

\section{Perbandingan Parameter Respons Gedung}

Parameter-parameter respons gedung pada semua model gedung yang memiliki ketidakberaturan massa pada masing-masing tingkat dibandingkan dengan model gedung beraturan. Parameter-parameter tersebut adalah gaya geser tingkat (story shear) dan simpangan antar lantai tingkat (story drift).

\section{Perbandingan Gaya Geser Tingkat (Story Shear)}

Perbandingan dari gaya geser tingkat dari model gedung G1 sampai G10 terhadap model gedung G0 berdasarkan analisis dinamik respons spektrum dapat dilihat melalui Gambar 6. Persentase peningkatan gaya geser tingkat 
model gedung G1 sampai G10 terhadap model gedung G0 berdasarkan semua metode analisis dapat dilihat di Tabel 2 sampai Tabel 5.

Pada Tabel 2 sampai Tabel 5 dapat dilihat juga gradasi warna yang menunjukan pembagian level keamanan suatu tingkat (story). Kotak yang memiliki warna kemerahan berarti memiliki peningkatan gaya geser tingkat yang sangat signifikan sehingga dianggap sangat berbahaya. Kotak yang memiliki warna keemasan berarti memiliki peningkatan gaya geser tingkat yang cukup signifikan sehingga dianggap masih cukup berbahaya. Kotak yang memiliki warna kekuningan berarti memiliki peningkatan gaya geser tingkat yang tidak terlalu signifikan sehingga dianggap sedikit berbahaya. Kotak yang memiliki warna kehijauan berarti memiliki peningkatan gaya geser tingkat yang kecil sehingga dianggap relatif tidak berbahaya.

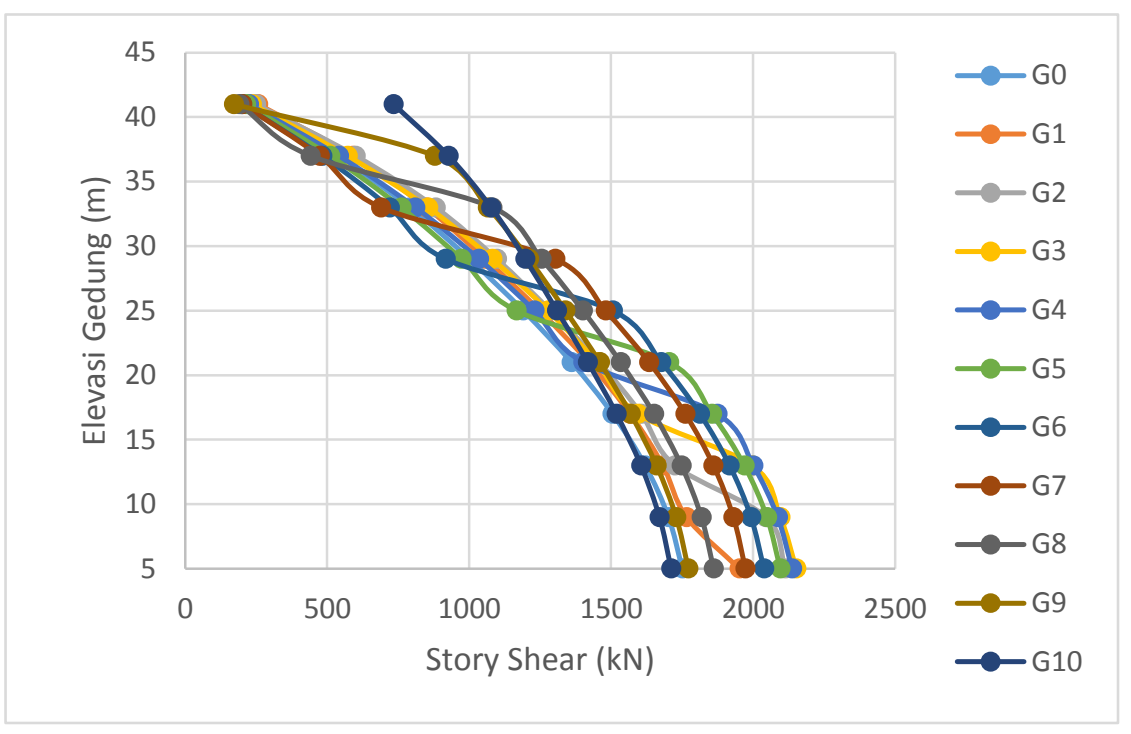

Gambar 6. Gaya Geser Tingkat Model Gedung G0 - G10 Berdasarkan Analisis Spektrum Respons

Tabel 2. Persentase Peningkatan Gaya Geser Tingkat Model Gedung G1 - G10 Terhadap Model Gedung G0 Berdasarkan Analisis Spektrum Respons

\begin{tabular}{|c|c|c|c|c|c|c|c|c|c|c|c|}
\hline \multirow{2}{*}{ Story } & \multirow{2}{*}{$\begin{array}{c}\text { Elevasi } \\
\text { (m) }\end{array}$} & \multicolumn{10}{|c|}{ Peningkatan Gaya Geser Tingkat - RS (\%) } \\
\hline & & G1 & G2 & G3 & G4 & G5 & G6 & G7 & G8 & G9 & G10 \\
\hline 10 & 41 & 13.8285 & 10.3443 & 4.3915 & -0.3196 & -5.0476 & -11.2555 & -10.8469 & -15.3253 & -24.1183 & 225.3645 \\
\hline 9 & 37 & 10.4430 & 12.2527 & 6.8486 & 1.0947 & -4.5500 & -9.8069 & -11.4513 & -17.3772 & 64.2088 & 73.3116 \\
\hline 8 & 33 & 7.3359 & 11.4604 & 8.1663 & 2.4491 & -3.8091 & -8.9643 & -12.8045 & 36.7977 & 34.7552 & 36.2049 \\
\hline 7 & 29 & 5.6712 & 9.6212 & 8.0138 & 3.2933 & -2.7800 & -8.3910 & 30.1965 & 25.3084 & 20.8686 & 19.6389 \\
\hline 6 & 25 & 4.8624 & 8.0195 & 7.3158 & 3.2901 & -2.0580 & 26.4710 & 24.3257 & 17.6450 & 12.4825 & 9.9600 \\
\hline 5 & 21 & 4.4780 & 7.1569 & 6.5250 & 3.0107 & 25.2024 & 23.2382 & 20.0558 & 12.6901 & 7.3281 & 4.2197 \\
\hline 4 & 17 & 4.1322 & 6.7089 & 5.9505 & 24.4906 & 23.2435 & 20.4232 & 17.0265 & 9.6797 & 4.2272 & 0.9171 \\
\hline 3 & 13 & 3.8502 & 6.4160 & 23.2757 & 23.5020 & 21.5511 & 18.3621 & 14.8378 & 7.8810 & 2.4674 & -0.9204 \\
\hline 2 & 9 & 3.7241 & 20.1608 & 23.1279 & 22.5974 & 20.3692 & 17.0691 & 13.4225 & 6.8203 & 1.5973 & -1.8556 \\
\hline 1 & 5 & 11.4531 & 20.7393 & 22.9117 & 22.0694 & 19.7055 & 16.4167 & 12.6898 & 6.2869 & 1.2155 & -2.2536 \\
\hline GF & 0 & - & - & - & - & - & - & - & - & - & - \\
\hline
\end{tabular}

Tabel 3. Persentase Peningkatan Gaya Geser Tingkat Model Gedung G1 - G10 Terhadap Model Gedung G0 Berdasarkan Analisis Riwayat Waktu - Hasil SIMQKE

\begin{tabular}{|c|c|c|c|c|c|c|c|c|c|c|c|}
\hline \multirow{2}{*}{ Story } & \multirow{2}{*}{$\begin{array}{c}\text { Elevasi } \\
\text { (m) }\end{array}$} & \multicolumn{10}{|c|}{ Peningkatan Gaya Geser Tingkat - SMQ (\%) } \\
\hline & & G1 & G2 & G3 & G4 & G5 & G6 & G7 & G8 & G9 & G10 \\
\hline 10 & 41 & 7.1706 & 11.6196 & 26.0149 & 17.1374 & 12.2221 & -13.2583 & -31.7518 & -29.7683 & -26.8499 & 233.3283 \\
\hline 9 & 37 & 8.6312 & 11.4164 & 21.2174 & 10.6840 & 10.7557 & -10.4716 & -27.1959 & -28.5763 & 66.6731 & 78.1808 \\
\hline 8 & 33 & 7.7523 & 7.7263 & 7.8616 & 8.0181 & 4.1695 & -10.1176 & -23.5402 & 27.0113 & 36.5855 & 36.3941 \\
\hline 7 & 29 & 4.2056 & 4.4894 & 6.8965 & 5.8328 & 3.7405 & -13.4470 & 22.7723 & 15.6924 & 22.0732 & 15.8537 \\
\hline 6 & 25 & 0.5416 & 2.2032 & 7.1888 & 7.2710 & 0.4964 & 14.8355 & 17.1188 & 10.5688 & 10.8987 & 4.4901 \\
\hline 5 & 21 & 0.4792 & 5.4207 & 7.9118 & 8.7588 & 15.5145 & 10.9033 & 14.6731 & 7.2273 & 2.4332 & 3.0513 \\
\hline 4 & 17 & -0.4186 & 7.8466 & 8.1682 & 29.4730 & 13.5177 & 7.3013 & 13.1041 & 4.7561 & -3.1499 & 1.8814 \\
\hline 3 & 13 & 1.6687 & 9.7249 & 28.4582 & 28.5684 & 11.9112 & 3.4454 & 11.3896 & 3.2150 & -4.0479 & 0.7467 \\
\hline 2 & 9 & 3.6410 & 23.0916 & 30.6047 & 29.2484 & 10.7047 & 0.0406 & 10.0663 & 2.6293 & -3.5992 & 2.8807 \\
\hline 1 & 5 & 9.3055 & 24.1779 & 31.9148 & 30.2835 & 10.8432 & -1.9061 & 9.4087 & 2.5057 & -2.8708 & 6.5959 \\
\hline GF & 0 & - & - & - & - & - & - & - & - & - & - \\
\hline
\end{tabular}


Tabel 4. Persentase Peningkatan Gaya Geser Tingkat Model Gedung G1 - G10 Terhadap Model Gedung G0 Berdasarkan Analisis Riwayat Waktu - Chuetsu-oki

\begin{tabular}{|c|c|c|c|c|c|c|c|c|c|c|c|}
\hline \multirow{2}{*}{ Story } & \multirow{2}{*}{$\begin{array}{c}\text { Elevasi } \\
\text { (m) }\end{array}$} & \multicolumn{10}{|c|}{ Peningkatan Gaya Geser Tingkat - CHT (\%) } \\
\hline & & G1 & G2 & G3 & G4 & G5 & G6 & G7 & G8 & G9 & G10 \\
\hline 10 & 41 & 7.0523 & 17.5180 & 37.4893 & 26.6021 & 15.1700 & 2.9372 & -18.4854 & -29.4175 & -31.2470 & 188.3588 \\
\hline 9 & 37 & 6.3295 & 21.4904 & 39.7005 & 28.5893 & 18.0333 & 4.2764 & -16.8940 & -28.4971 & 54.1228 & 46.9812 \\
\hline 8 & 33 & 5.9462 & 20.2424 & 36.0281 & 25.1819 & 15.2790 & 1.0259 & -19.8362 & 22.1134 & 20.4063 & 6.2668 \\
\hline 7 & 29 & 5.7679 & 16.7198 & 28.7577 & 18.6771 & 9.1890 & -2.8508 & 17.1489 & 8.2992 & -0.1909 & -12.6160 \\
\hline 6 & 25 & 5.2028 & 12.4389 & 20.1179 & 11.3548 & 1.8563 & 21.6313 & 10.1815 & -1.6735 & -11.8958 & -15.6396 \\
\hline 5 & 21 & 4.6585 & 7.9471 & 12.2682 & 5.0366 & 25.7101 & 17.6382 & 5.8136 & -3.9411 & -10.0380 & -13.1652 \\
\hline 4 & 17 & 6.7373 & 4.5779 & 4.8427 & 22.5239 & 26.9368 & 14.8706 & 5.0071 & -2.3432 & -5.1388 & -10.6534 \\
\hline 3 & 13 & 7.3968 & 2.1436 & 27.6143 & 23.7894 & 27.4665 & 14.5457 & 6.7310 & -0.3838 & -0.4590 & -9.1075 \\
\hline 2 & 9 & 5.3220 & 14.6499 & 29.7805 & 24.9876 & 27.6900 & 14.2959 & 8.9181 & 3.5332 & 4.2919 & -7.1310 \\
\hline 1 & 5 & 6.0611 & 15.6840 & 31.1425 & 25.8049 & 27.8320 & 14.1696 & 10.6100 & 6.4767 & 7.5461 & -5.7693 \\
\hline$\overline{G F}$ & 0 & - & - & - & - & - & - & - & - & - & - \\
\hline
\end{tabular}

Tabel 5. Persentase Peningkatan Gaya Geser Tingkat Model Gedung G1 - G10 Terhadap Model Gedung G0 Berdasarkan Analisis Riwayat Waktu - Niigata

\begin{tabular}{|c|c|c|c|c|c|c|c|c|c|c|c|}
\hline \multirow{2}{*}{ Story } & \multirow{2}{*}{$\begin{array}{c}\text { Elevasi } \\
(\mathrm{m})\end{array}$} & \multicolumn{10}{|c|}{ Peningkatan Gaya Geser Tingkat - NGT (\%) } \\
\hline & & G1 & G2 & G3 & G4 & G5 & G6 & G7 & G8 & G9 & G10 \\
\hline 10 & 41 & 13.9844 & 3.8479 & 5.0182 & -2.6205 & -1.4843 & -4.7923 & -1.1012 & -11.5304 & -18.7288 & 263.0305 \\
\hline 9 & 37 & 6.4407 & 7.7473 & 10.3470 & 2.5338 & 3.1564 & -0.0559 & 2.9645 & -8.9565 & 83.9501 & 95.6154 \\
\hline 8 & 33 & 5.5266 & 7.1054 & 11.3414 & 3.2650 & 3.7657 & 1.4932 & 2.6617 & 54.0419 & 45.8423 & 53.5227 \\
\hline 7 & 29 & 4.8657 & 7.7330 & 11.6574 & 4.5791 & 4.8913 & 3.0657 & 53.8532 & 37.2940 & 26.6984 & 34.8595 \\
\hline 6 & 25 & 2.9880 & 6.4518 & 9.9738 & 4.5386 & 4.2542 & 43.0634 & 41.1861 & 24.2283 & 15.1144 & 21.9883 \\
\hline 5 & 21 & 1.1720 & 5.6169 & 8.8614 & 5.0855 & 32.4332 & 37.5497 & 32.7521 & 15.6799 & 8.5407 & 14.1162 \\
\hline 4 & 17 & 1.2311 & 5.0370 & 8.3737 & 28.8924 & 29.4774 & 34.3187 & 27.0550 & 10.1229 & 4.5523 & 9.3620 \\
\hline 3 & 13 & 0.9124 & 4.5027 & 24.0292 & 28.5273 & 27.5410 & 32.2062 & 23.0404 & 6.6451 & 2.1326 & 6.3405 \\
\hline 2 & 9 & 0.4076 & 13.2146 & 25.1286 & 29.1178 & 25.9426 & 30.3388 & 20.1019 & 6.6418 & 1.2828 & 4.1327 \\
\hline 1 & 5 & 4.3808 & 12.8107 & 25.9309 & 29.8149 & 24.7749 & 29.0862 & 18.4022 & 6.8548 & 0.9606 & 2.8132 \\
\hline GF & 0 & - & - & - & - & - & - & - & - & - & - \\
\hline
\end{tabular}

Setelah dilakukan pengamatan pada Tabel 2 sampai Tabel 5, ketidakberaturan massa pada suatu tingkat tidak hanya mengakibatkan peningkatan pada tingkat tersebut saja, namun juga menyebabkan tingkat-tingkat lainnya mengalami peningkatan. Pada penelitian ini penulis menggunakan suatu pendekatan yaitu, jika terjadi peningkatan gaya geser tingkat lebih besar dari 10\%, tingkat tersebut dianggap mengalami peningkatan gaya geser yang cukup signifikan. Tabel 6 menunjukan banyaknya tingkat yang mengalami peningkatan gaya geser pada masing-masing pemodelan gedung pada arah $\mathrm{X}$ dan Tabel 7 pada arah $\mathrm{Y}$.

Tabel 6. Banyaknya Tingkat yang Mengalami Peningkatan Gaya Geser Lebih Besar dari 10\% pada Masing-Masing Model pada Arah X

\begin{tabular}{lccccc}
\hline \multirow{2}{*}{ Model } & \multicolumn{5}{c}{ Banyaknya Tingkat } \\
\cline { 2 - 7 } & RS & TH - SMQ & TH - CHT & TH - NGT & Average \\
\hline G10 & 4 & 4 & 2 & 6 & 4 \\
\hline G9 & 4 & 4 & 2 & 4 & 4 \\
\hline G8 & 4 & 3 & 1 & 5 & 3 \\
\hline G7 & 7 & 6 & 3 & 7 & 6 \\
\hline G6 & 6 & 2 & 6 & 6 & 5 \\
\hline G5 & 5 & 7 & 8 & 5 & 6 \\
\hline G4 & 4 & 6 & 9 & 4 & 6 \\
\hline G3 & 3 & 5 & 9 & 6 & 6 \\
\hline G2 & 5 & 4 & 7 & 2 & 5 \\
\hline G1 & 3 & 0 & 0 & 1 & 1 \\
\hline
\end{tabular}

Tabel 7. Banyaknya Tingkat yang Mengalami Peningkatan Gaya Geser Lebih Besar dari 10\% pada Masing-Masing Model pada Arah Y

\begin{tabular}{cccccc}
\hline \multirow{2}{*}{ Model } & \multicolumn{5}{c}{ Banyaknya Tingkat } \\
\cline { 2 - 7 } & RS & TH - SMQ & TH - CHT & TH - NGT & Average \\
\hline G10 & 5 & 4 & 5 & 6 & 5 \\
\hline G9 & 4 & 4 & 5 & 5 & 5 \\
\hline G8 & 5 & 3 & 4 & 5 & 4 \\
\hline G7 & 7 & 5 & 4 & 7 & 6 \\
\hline G6 & 6 & 2 & 6 & 8 & 6 \\
\hline G5 & 5 & 2 & 5 & 7 & 5 \\
\hline G4 & 4 & 5 & 8 & 7 & 6 \\
\hline G3 & 3 & 5 & 9 & 8 & 6 \\
\hline G2 & 5 & 2 & 5 & 7 & 5 \\
\hline G1 & 3 & 0 & 2 & 5 & 3 \\
\hline
\end{tabular}

2. Perbandingan Simpangan Antar Lantai Tingkat (Story Drift)

Perbandingan masing-masing simpangan antar lantai tingkat (yang telah diperbesar) terhadap batasan yang diizinkan pada setiap tingkat dapat dilihat pada Gambar 7 sampai Gambar 10. Pada pembahasan subbab ini, hanya ditampilkan hasil pada gedung arah X saja. Hasil yang didapat pada gedung arah X dianggap sudah dapat mewakili hasil pada gedung arah Y. 


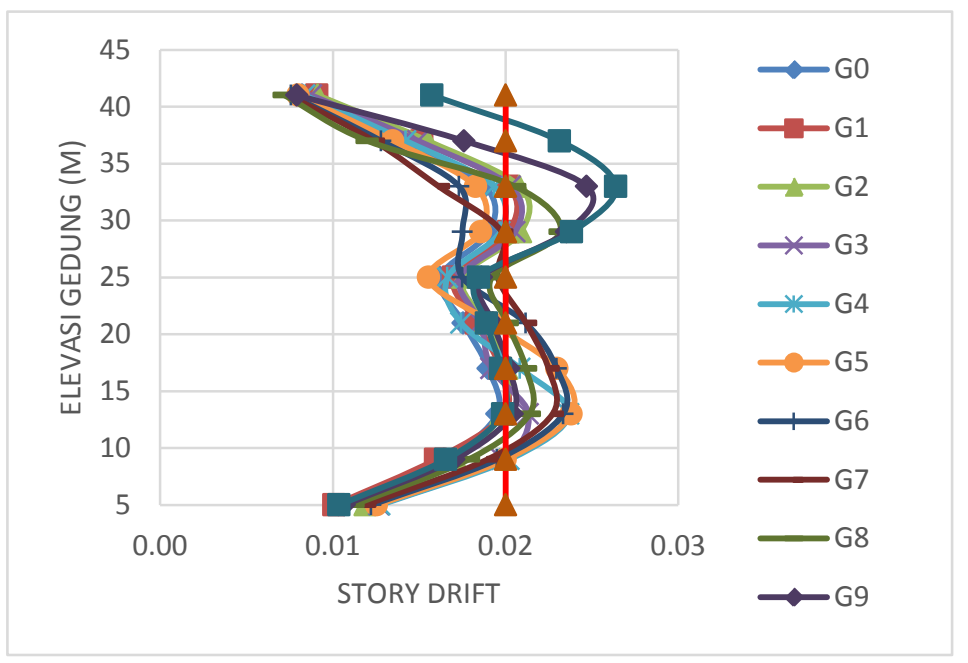

Gambar 7. Grafik Perbandingan Simpangan Antar Lantai Tingkat Terhadap Simpangan Izin pada Model Gedung G0 - G10 Berdasarkan Analisis Spektrum Respons

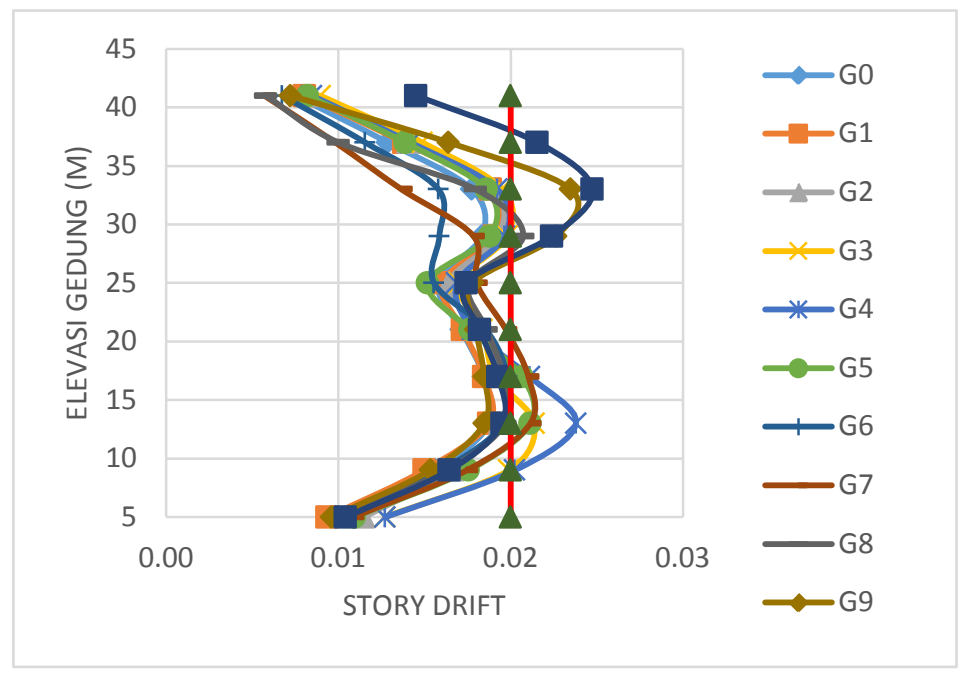

Gambar 8. Grafik Perbandingan Simpangan Antar Lantai Tingkat Terhadap Simpangan Izin pada Model Gedung G0 - G10 Berdasarkan Analisis Riwayat Waktu - Hasil SIMQKE

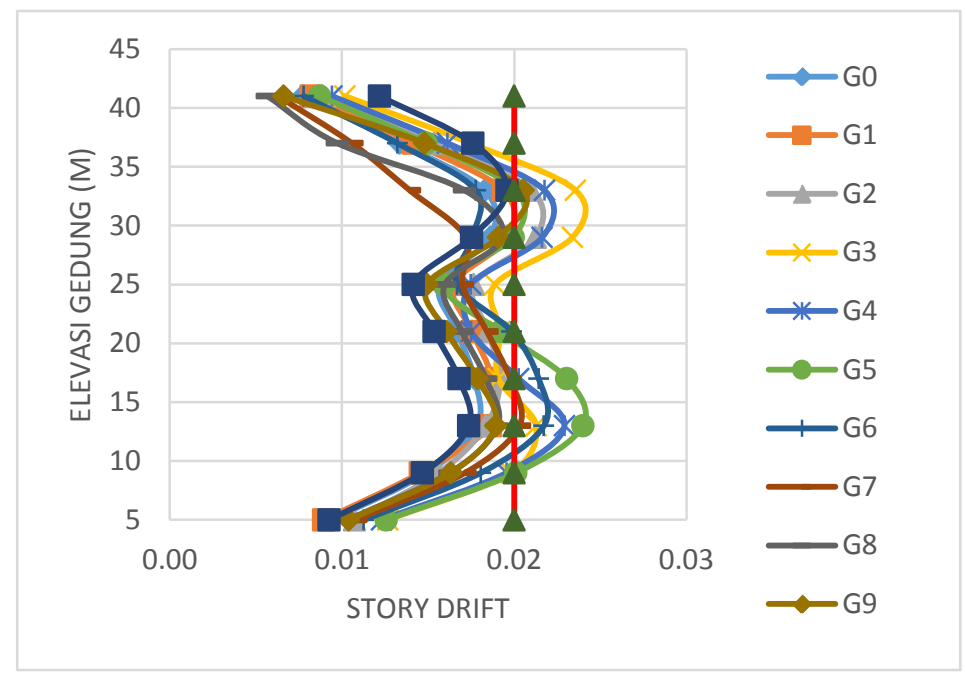

Gambar 9. Grafik Perbandingan Simpangan Antar Lantai Tingkat Terhadap Simpangan Izin pada Model Gedung G0 - G10 Berdasarkan Analisis Riwayat Waktu - Chuetsu-oki 


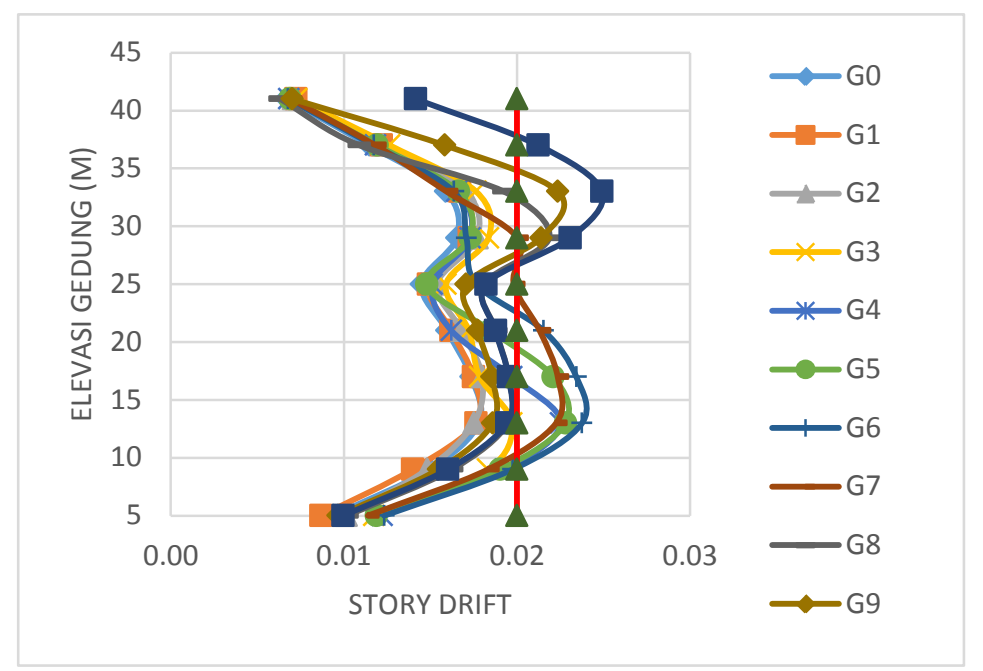

Gambar 10. Grafik Perbandingan Simpangan Antar Lantai Tingkat Terhadap Simpangan Izin pada Model Gedung G0 - G10 Berdasarkan Analisis Riwayat Waktu - Niigata

Berdasarkan Gambar 7 sampai Gambar 10 di atas dapat dilihat, ketidakberaturan massa pada suatu tingkat mengakibatkan peningkatan simpangan antar lantai tingkat (story drift) pada tingkat-tingkat lainnya dalam suatu gedung. Tabel 8 dan Tabel 9 menunjukan banyaknya tingkat yang mengalami simpangan antar lantai tingkat melebihi simpangan batas pada masing-masing tingkat. Secara rata-rata dari keempat hasil analisis, model yang memiliki paling banyak memiliki simpangan antar lantai tingkat memlebihi simpangan batas adalah pada model gedung G4, G5, dan G7 pada arah X dan model G9 dan G10 pada arah Y.

Tabel 8. Banyaknya Tingkat yang Melebihi Batas Simpangan Antar Lantai pada Masing - Masing Model Gedung pada Arah X

\begin{tabular}{cccccc}
\hline \multirow{2}{*}{ Model } & \multicolumn{5}{c}{ Banyaknya Tingkat } \\
\cline { 2 - 6 } & RS & TH - SMQ TH - CHT TH - NGT & Average \\
\hline G10 & 3 & 3 & 0 & 3 & 2 \\
\hline G9 & 4 & 2 & 1 & 2 & 2 \\
\hline G8 & 5 & 1 & 0 & 1 & 2 \\
\hline G7 & 3 & 2 & 1 & 4 & 3 \\
\hline G6 & 3 & 0 & 2 & 3 & 2 \\
\hline G5 & 2 & 2 & 4 & 2 & 3 \\
\hline G4 & 3 & 3 & 4 & 1 & 3 \\
\hline G3 & 3 & 1 & 3 & 0 & 2 \\
\hline G2 & 3 & 0 & 2 & 0 & 1 \\
\hline G1 & 2 & 0 & 0 & 0 & 1 \\
\hline G0 & 0 & 0 & 0 & 0 & 0 \\
\hline
\end{tabular}

Tabel 9. Banyaknya Tingkat yang Melebihi Batas Simpangan Antar Lantai pada Masing - Masing Model Gedung pada Arah Y

\section{Penentuan Level Keamanan Masing-Masing Tingkat yang Memiliki Ketidakberaturan Massa}

Berdasarkan pembahasan mengenai dampak ketidakberaturan di atas, maka akan dicoba melakukan suatu pendekatan untuk dapat mengetahui pada tingkat mana yang diperkirakan relatif aman hingga berbahaya, jika direncanakan suatu tingkat akan memiliki ketidakberaturan massa. Penilaian tingkat keamanan dilakukan berdasarkan pengaruh letak tingkat yang mengalami ketidakberaturan massa terhadap 4 faktor sebagai berikut:

1. Tingkat keamanan berdasarkan model gedung yang memiliki persentase kenaikan gaya geser tingkat (story shear) paling besar pada suatu story akibat adanya ketidakberaturan massa, yaitu pada model gedung G10

2. Tingkat keamanan berdasarkan banyaknya story lain yang ikut mengalami peningkatan gaya geser tingkat (story shear) lebih dari 10\% akibat adanya ketidakberaturan massa pada suatu story pada arah X dan arah Y.

3. Tingkat keamanan berdasarkan model gedung yang memiliki persentase penyimpangan dari simpangan antar lantai tingkat (story drift) paling besar pada suatu story terhadap simpangan antar lantai izin pada akibat adanya ketidakberaturan massa, yaitu pada model gedung G10. 
4. Tingkat keamanan berdasarkan banyaknya story lain yang memiliki simpangan antar lantai tingkat (story drift) yang melewati simpangan batas akibat adanya ketidakberaturan massa pada suatu story, pada arah $\mathrm{X}$ dan arah Y.

Tabel penilaian tingkat keamanan letak ketidakberaturan massa dapat dilihat pada Tabel 10

Tabel 10. Level Keamanan Masing-Masing Tingkat (Story) yang Memiliki Ketidakberaturan Massa

\begin{tabular}{|c|c|c|c|c|c|c|c|}
\hline \multirow[b]{2}{*}{ Story } & \multicolumn{6}{|c|}{ Faktor Penilaian } & \multirow[b]{2}{*}{ Rata - Rata } \\
\hline & $\begin{array}{c}\text { Peningkatan Gaya } \\
\text { Geser } \\
\text { Tingkat Terbesar } \\
\text { (G10) }\end{array}$ & $\begin{array}{c}\text { Banyaknya Tingkat } \\
\text { yang } \\
\text { Mengalami } \\
\text { Peningkatan } \\
\text { Gaya Geser Tingkat } \\
\text { Arah X }\end{array}$ & $\begin{array}{c}\text { Banyaknya } \\
\text { Tingkat yang } \\
\text { Mengalami } \\
\text { Peningkatan } \\
\text { Gaya Geser } \\
\text { Tingkat Arah Y }\end{array}$ & $\begin{array}{l}\text { Simpangan Antar } \\
\text { Lantai Tingkat } \\
\text { Maksimum (G10) }\end{array}$ & $\begin{array}{c}\text { Banyaknya } \\
\text { Tingkat yang } \\
\text { Melebihi } \\
\text { Simpangan } \\
\text { Batas Arah X }\end{array}$ & $\begin{array}{l}\text { Banyaknya } \\
\text { Tingkat yang } \\
\text { Melebihi } \\
\text { Simpangan } \\
\text { Batas Arah Y }\end{array}$ & \\
\hline 10 & 225.3645 & 4 & 5 & 0.0157 & 2 & 7 & Berbahaya \\
\hline 9 & 73.3116 & 4 & 5 & 0.0231 & 2 & 7 & Berbahaya \\
\hline 8 & 36.2049 & 3 & 4 & 0.0264 & 2 & 6 & Cukup Berbahaya \\
\hline 7 & 19.6389 & 6 & 6 & 0.0238 & 3 & 6 & Berbahaya \\
\hline 6 & 9.9600 & 5 & 6 & 0.0184 & 2 & 4 & Tidak Terlalu Berbahaya \\
\hline 5 & 4.2197 & 6 & 5 & 0.0189 & 3 & 4 & Berbahaya \\
\hline 4 & 0.9171 & 6 & 6 & 0.0197 & 3 & 5 & Berbahaya \\
\hline 3 & -0.9204 & 6 & 6 & 0.0198 & 2 & 6 & Berbahaya \\
\hline 2 & -1.8556 & 5 & 5 & 0.0165 & 1 & 4 & Relatif Aman \\
\hline 1 & -2.2536 & 1 & 3 & 0.0103 & 1 & 4 & Relatif Aman \\
\hline
\end{tabular}

\section{KESIMPULAN}

Berdasarkan hasil pembahasan dapat disimpulkan bahwa:

1. Ketidakberaturan massa pada suatu tingkat dapat menyebabkan peningkatan dan juga penurunan gaya geser tingkat (story shear), pada tingkat-tingkat lain selain tingkat yang memiliki ketidakberaturan massa tersebut. Ketidakberaturan massa pada suatu tingkat juga dapat menyebabkan simpangan antar lantai tingkat (story drift) pada tingkat-tingkat lainnya melebihi simpangan izin.

2. Berdasarkan penilaian pada pengaruh penempatan suatu tingkat yang memiliki ketidakberaturan massa terhadap beberapa faktor penilaian pada subbab 4.7, dapat diketahui bahwa tingkat tingkat ke-10, 9, 7, 5, 4, 3 (atau 100\%, 90\%, 70\%, 50\%, 40\%, 30\% dari tinggi total gedung) dinyatakan berbahaya untuk memiliki ketidakberaturan massa. Sangat tidak disarankan untuk memodelkan ketidakberaturan massa pada bagian-bagian gedung tersebut.

3. Pada tingkat 2 dan 1 (atau 20\% dan 10\% dari tinggi total gedung) dinyatakan relatif aman jika memiliki ketidakberaturan massa. Namun, jika pada tingkat ke-2 dan 1 tidak memungkinkan untuk direncanakan sebagai tingkat yang akan memiliki ketidakberaturan massa, maka pada tingkat ke-6 atau tingkat ke-8 masih dapat menjadi pertimbangan.

Kesimpulan-kesimpulan yang didapat dari hasil penelitian di atas hanya berlaku untuk pemodelan struktur dengan ketentuan dan asumsi yang dijelaskan pada Bab 3 atau dengan kata lain kesimpulan di atas belum bersifat umum. Perlu dilakukan penelitian lebih lanjut menggunakan ketentuan dan asumsi yang berbeda.

\section{SARAN}

1. Memodelkan gedung menggunakan asumsi yang kurang lebih sama namun dengan tinggi yang berbeda

2. Memodelkan gedung menggunakan asumsi-asumsi yang berbeda untuk tinggi gedung yang relatif sama

3. Memodelkan ketidakberaturan massa hanya terjadi di beberapa ruangan (tidak di seluruh tingkat)

\section{DAFTAR PUSTAKA}

Christiawan, Ignatius, Andreas Triwiyono dan Hary Christady. (2008). "Evaluasi Kinerja dan Perkuatan Struktur Gedung Guna Alih Fungsi Bangunan (Studi Kasus: Perubahan Fungsi Ruang Kelas Menjadi Ruang Perpustakaan pada Lantai 11 Gedung G Universitas Semarang”. Forum Teknik Sipil. No. XVIII

Computer \& Structure, Inc (CSI). (2017). CSI Analysis Reference Manual. America: Computer \& Structure, Inc

Departemen Pekerjaan Umum. (2012). Tata Cara Perencanaan Ketahanan Gempa untuk Sktruktur Bangunan Gedung dan Non Gedung (SNI 1726:2012). Jakarta: Badan Standarisasi Nasional

FEMA 451. (2006). NEHRP Recommended Provisions: Design Examples. Building Seismic Safety Council National Institute of Building Sciences. Washington D.C.

Indarto, Himawan, Hanggoro Tri Cahyo A., dan Kukuh C. Adi Putra. (2013). Aplikasi SNI Gempa 1726:2012 for Dummies. Semarang: Shortcourse, Teknik Sipil UNNES - A Tribute to Bambang Dewasa

Sadashiva, Vinod, Gregory A. MaeRae dan Bruce L. Deam. (2009). "Determination of Structural Irregularity Limits - Mass Irregularity Example”. Bulletin of The New Zealand Society for Earthquake Engineering. Vol. 42. 